\title{
Sin Stocks in Various Litigation Risk: A Case Study in 14 Countries
}

\author{
Iis Nurasiah ${ }^{1}$, Nugraha $^{2}$, Disman $^{3}$, Rozmita Dewi Yuniarti ${ }^{4}$ \\ \{buiisnurasiah@gmail.com¹, nugraha@upi.edu², disman@upi.edu ${ }^{3}$,rozmita.dyr@upi.edu ${ }^{4}$ \} \\ Universitas Bina Bangsa, Serang, Indonesia ${ }^{1}$, Universitas Pendidikan Indonesia, Bandung, Indonesia ${ }^{2}$, \\ Universitas Pendidikan Indonesia, Bandung, Indonesia ${ }^{3}$, Universitas Pendidikan Indonesia, Bandung, \\ Indonesia $^{4}$
}

\begin{abstract}
The capital market has an important role for the economy of a country with stock as the most important instrument. One of the most interesting stock is the sin stock because it provides a fairly high return compared to other stocks. However, the existence of the sin stock is considered contrary to a social norm, especially legal norm. In this study, we will examine whether there are differences in sin stock returns in 3 different litigation risk groups using the rule of law as the indicator. This type of study is descriptive with a quantitative approach. The number of samples was 63 stocks from 14 countries with an observation period of 21 years, from 2000 to 2020. To test the hypothesis, was using the Kruskal Wallis test and followed by the Man Whitney test as the post hoc test. The test results show that there are differences in sin stock returns in 3 different litigation risk groups, namely high, middle, and low in 14 countries. A significant difference occurs between low and medium litigation risk as well as between low and high. Meanwhile, there is no difference between medium and high.
\end{abstract}

Keywords: Litigation risk, Rule of law, Stock return, Sin stock return, Sin industry.

\section{Introduction}

The capital market has an important role for the economy of a country because it performs two functions at once. First, the capital market's function as a means for business funding or as a means for companies to obtain funds from investors. Funds obtained from the capital market can be used for business development, expansion, additional working capital and others. Both capital markets are a means for people to invest in various financial instruments such as stocks, bonds, mutual funds, derivatives and others. Thus, the public can place the funds they own according to the characteristics of the profit and risk of each instrument.

From the various financial instruments traded on the capital market, stocks are the most popular instrument. Stocks are investment instrument that many investors choose because they are able to provide interesting returns, both dividend and capital gain. Of course, a high level of return is accompanied by a large level of risk (High risk, high return). One of the most interesting stocks is the sin stock. Sin stock provides high returns, however, sin stock also contains high risks because it is related to social norms that apply to a country. Sin stock is stock issued by public companies involved in the production of alcohol, tobacco and gambling 
[1]. This type of company is considered to violate social norms. Salaber [2] proved the relationship between social norms, namely religion, litigation risk and excise tax rates with the sin industry where sin stock returns are the object of the research. His empirical research suggested that sin stocks return is higher in countries that face litigation risk and high tax rates. This is what underlies the author to make a legal factor, namely litigation risk, as the basis for this study.

In this study, we will examine whether there are differences in sin stock returns in 3 different litigation risk groups, namely high, middle and low in 14 countries using the rule of law as an indicator.

\section{Literature Review}

\subsection{Sin Industry and Stock Return}

Sin Industry is an industry that produces products where most of people consider the product unethical or immoral. The following is the definition and coverage of the sin industry based on Fabozzi, F., K.C. Ma., Oliphant [3]:

\begin{tabular}{ll}
\hline Sin Industry & Products \& Services \\
\hline Adult Services & Provides subscription-based adult entertainment \\
Provides adult products and online entertainment \\
Provides dating and chat services \\
Owns and operates adult-themed clubs \\
Manufactures and sells adult products \\
Provides adult media content \\
Holding company with an adult-themed division \\
Produces malt for breweries \\
Produces cork stoppers for wine \\
Produces and distributes wine \\
Owns and operates establishments that sell alcohol \\
Manufactures and distributes alcoholic beverages \\
Manufactures ethanol used in liquor \\
Imports foreign alcohols \\
Holding company with an alcohol division \\
Engages in retailing and brewing beer \\
Distils liquors \\
Designs bottles for liquor and wine \\
Provides tissue engineering and gene therapy \\
Provides biomedical research of genome applications \\
Conducts animal testing and creates gene-modified mice \\
Creates injectable aesthetic products \\
Experiments with animal genes for producing proteins \\
Conducts genetic testing and genome research \\
Conducts nanotechnology research for treatment of STDs \\
Conducts stem cell-based research \\
Produces products for military use \\
Produces firearms \\
Holding company with a firearms division \\
Creates software applications used for the military \\
Involved in aspects of gambling and operates bars \\
Provides digital fortune-telling content \\
Supplies and/or produces gambling-related products \\
Owns and/or operates establishments that allow gambling \\
Conducts gambling servicing \\
Makes paper used to wrap various parts of the cigarette \\
Develops methods to reduce toxins in tobacco \\
Produces tobacco-based products \\
Sells pipes, rolling tobacco, and lighters \\
Holding company with a tobacco division \\
Tobacco
\end{tabular}

Figure 1. The Definition and Scope of Sin Industry 
The 3 largest sin industries and the focus of study are tobacco, alcohol, and gambling.

1. Tobacco

Tobacco is an agricultural product that is processed from the leaves of plants of the genus nicotiana. Tobacco can be consumed, used as a pesticide and in the form of nicotine tetra can be used as medicine. Tobacco products produced by the sin industry based on The Tobacco Atlas *6th edition, 2018 include Cigarettes, Cigar, Heat-not-burn, E-cigarettes, Bidis.

2. Alcohol

Alcohol is an organic compound that has a hydroxyl group (-OH) attached to a carbon atom, which itself is attached to a hydrogen atom and/or another carbon atom. By substituting $-\mathrm{OH}$ to $\mathrm{H}$ from $\mathrm{CH} 4$, we get $\mathrm{CH} 3 \mathrm{OH}$ which is known as methanol. The functional formula for alcohol is $\mathrm{OH}$ with the general formula for $\mathrm{ROH}$ alcohol, where $\mathrm{R}$ is an alkyl or alkyl group substitution [4].

3. Gambling

Gambling (sometimes called gaming) ranks the 3rd in the sin industry. The gambling industry has experienced rapid and consistent growth since the enactment of the law. Since the law was implemented, this industry has generated huge amounts of international income. The gambling and gaming industries provide employment for a large part of society. The gambling and gaming industry consist of all types of gambling or betting, which includes slot machines, card games, roulette, sports betting, online games, bingo, card games, charity lotteries and others created in a large spectrum of bingo halls, casinos, betting, various lotteries, and charity.

Stock return according to Dermawan [5] is a rate of return in the form of profits or losses obtained by investors from the value invested. So, sin stock return can be interpreted as the rate of return obtained by investors from the value invested in stock issued by the sin company/industry.

Realized return can be calculated using historical data, namely by measuring the rate of change in stock prices, so that it can be formulated as follows [6] :

$$
\begin{aligned}
& \text { Stock Return } t=\quad \stackrel{P_{t}-P_{t-1}}{ } \\
& P_{t-1} \\
& \mathrm{P}_{\mathrm{t}} \quad=\text { Stock price in } \mathrm{t} \text { time } \\
& \mathrm{P}_{\mathrm{t}-1} \quad=\text { Stock price in } \mathrm{t}-1 \text { time }
\end{aligned}
$$

\subsection{Litigation Risk}

Litigation risk in a country can be defined as the risk for a company located in that country which makes it as the subject of lawsuits [2]. This includes litigation costs such as current and future health care and recovery costs.

The litigation risk faced by a company can come from individuals (customers), organizations and even countries. They make claims for displeasure with services and products, disruption and loss of service, injuries and hazards related to operations, staff, products and services.

This risk is relatively higher for 'sin' companies than for other companies, but also depends on the company's environmental laws, such as law enforcement or the possibility of being sued. 
The litigation risk faced by sin companies certainly in their products. However, sin products (tobacco, alcohol and gambling) are products that can cause addiction and interference with its users. The disturbances in question include physical health, mental health and even social environmental problems. Therefore, the industry engaged in this field certainly requires definite regulation and legal protection. Salaber [2] concluded that countries with high levels of litigation produce higher sin stock returns than countries with low levels of litigation.

There are several indicators that can be used to measure litigation risk, including the level of rule of law in a country, the number of lawyers per capita of a country and it can also be measured by the number of judicial cases per population in one year in a country.

According to Salaber [2], litigation risk in this study is measured using the rule of law. La Porta, Lopez-de-Silanes, Shleifer and Vishny [7] defined the rule of law as an assessment of the tradition of law and order in a country. In this study, the sample countries are classified into 3, namely low litigation risk, medium litigation risk and high litigation risk.

The hypothesis that can be drawn from this theory are:

1. There are differences in sin stock returns in 3 categories of litigation risk (low, medium, high) in 14 countries.

2. There is a significant difference in sin stock return between low-high litigation risk.

3. There is no significant difference in sin stock returns between medium-high litigation risk and between low-medium litigation risk.

\section{Methods}

This type of this study is descriptive with a quantitative approach. The number of samples was 63 stocks from 14 countries with an observation period of 21 years, from January 2000 to April 2020. The data used is secondary data in the form of monthly stock data accessed through the yahoo finance web to be processed into annual data. Thus, the amount of data obtained in this study is 1323 data.

The rule of law data are obtained from the world bank and then divided into 3 categories based on the rank value. Values with a rank of 0-33 are low, 34-66 are middle, and 67-100 are high.

Table 1. Total sin stock and level of litigation risk

\begin{tabular}{clcl}
\hline No & Country & Sin Stock & Rule of Law \\
1 & Indonesia & 3 & Low \\
2 & Brazil & 1 & Medium \\
3 & China & 18 & Medium \\
4 & Mexico & 1 & Medium \\
5 & Malaysia & 3 & Medium \\
6 & India & 1 & Medium \\
7 & Turkey & 2 & Medium \\
8 & Taiwan & 1 & Medium \\
9 & Australia & 1 & High \\
10 & Canada & 2 & High \\
\hline
\end{tabular}




\begin{tabular}{llcl}
\hline 11 & Chile & 2 & High \\
12 & England & 4 & High \\
13 & Hongkong & 1 & High \\
14 & USA & 23 & High \\
\hline
\end{tabular}

Data normality was tested using Kolmogrov Smirnov and homogeneity tests using Levene's statistic.

To answer the first hypothesis, the Kruskall Wallis test was used to determine whether there was a statistically significant difference between two or more groups of independent variables on the dependent variable with a numerical data scale (interval / ratio).

Furthermore, the post hoc test was carried out using Man Whitney to answer the second hypothesis. This test is conducted to assess between categories whether there are significant differences.

\section{Result and Discussion}

All valid data means complete and legible (table 1), data are not normally distributed because the sig value is $0.000<0.05$ (table 2) but are in the same group or homogeneous because of sig. $0.286>0.05$ (table 3 ).

Table 1. Case Processing Summary

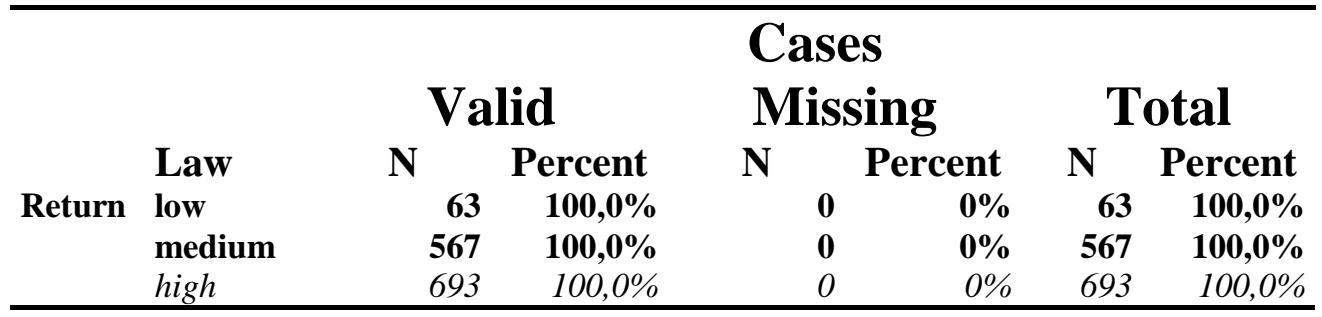

Table 2. Tests of Normality

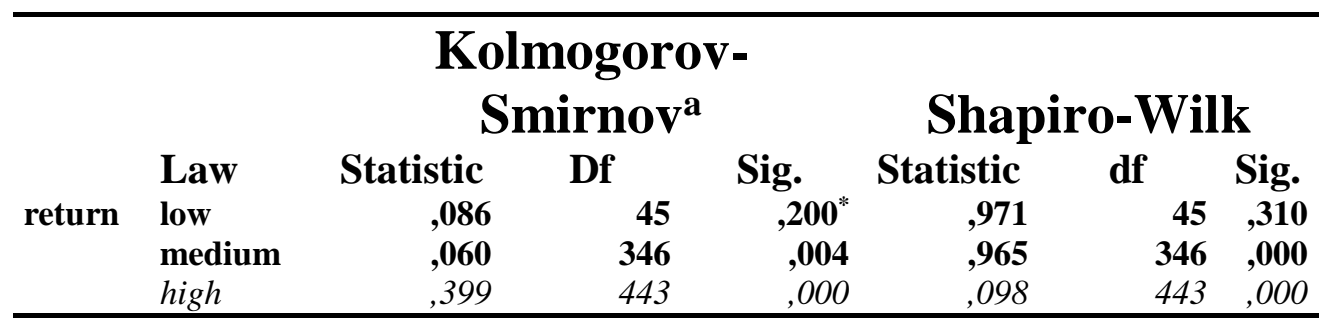

*. This is a lower bound of the true significance.

a. Lilliefors Significance Correction 
Table 3. Test of Homogeneity of Variances

Return

\section{Levine Statistic df1 df2 Sig.

$\begin{array}{llll}1,253 & 2 & 1320 & , 286\end{array}$

It can be seen in Table 4 that the Kruskal Wallis test statistic shows that the probability value (Sig.) $=0.001$, so that $0.001<0.05$, then Ho is rejected. So it can be concluded that there are differences in returns on the low, medium and high ligases risk.

Table 4. Kruskal-Wallis Test Ranks

\begin{tabular}{rlrr}
\hline \multirow{4}{*}{ Return } & Law & N & Mean Rank \\
& Low & $\mathbf{6 3}$ & $\mathbf{3 9 3 , 4 3}$ \\
& Medium & $\mathbf{5 6 7}$ & $\mathbf{4 5 3 , 3 6}$ \\
& High & $\mathbf{6 9 3}$ & $\mathbf{3 9 1 , 9 4}$ \\
Total & 1323 & \\
\hline
\end{tabular}

Test Statistics ${ }^{a, b}$

a. Kruskal Wallis Test

b. Grouping Variable: Law

\begin{tabular}{lr}
\hline & Return \\
Chi-Square & 13,101 \\
Df & 2 \\
Asymp. Sig. &, 001 \\
\hline
\end{tabular}

Based on the Table 5, 6 and 7 below, the result of Mann-Whitney statistic test with alpha 0,05 are obtained as follow :

1) Low-medium resulting value sig. 0,118>0,05 (H0 rejected)

2) Low-high resulting value sig. 0,973>0,05 (H0 rejected)

3) Medium-high resulting value sig. $0,000<0,05$ ( $\mathrm{H} 0$ accepted)

Table 5. Mann-Whitney Test Low-Medium Ranks

\begin{tabular}{rlrrr}
\hline & & & \multicolumn{1}{c}{ Mean } & \multicolumn{1}{c}{ Sum of } \\
& Law & N & Rank & Ranks \\
return & Low & $\mathbf{6 3}$ & $\mathbf{1 7 1 , 2 6}$ & $\mathbf{7 7 0 6 , 5 0}$ \\
& Medium & $\mathbf{5 6 7}$ & $\mathbf{1 9 9 , 2 2}$ & $\mathbf{6 8 9 2 9 , 5 0}$ \\
& Total & $\mathbf{6 3 0}$ & & \\
\hline
\end{tabular}

Test Statistics ${ }^{\mathrm{a}}$

a.Grouping Variable: Law 


\begin{tabular}{lr}
\hline & \multicolumn{1}{c}{ Return } \\
Mann-Whitney U & $\mathbf{6 6 7 1 , 5 0 0}$ \\
Wilcoxon W & $\mathbf{7 7 0 6 , 5 0 0}$ \\
Z & $\mathbf{- 1 , 5 6 1}$ \\
Asymp. Sig. (2-tailed) &, 118 \\
\hline
\end{tabular}

Table 6. Mann-Whitney Test Low-High Ranks

\begin{tabular}{rlrrr}
\hline & & & \multicolumn{1}{c}{ Mean } & \multicolumn{1}{c}{ Sum of } \\
\multirow{4}{*}{ Return } & Law & N & Rank & \multicolumn{1}{c}{ Ranks } \\
& Low & 63 & $\mathbf{2 4 5 , 1 8}$ & 11033,00 \\
& High & 693 & 244,43 & 108283,00 \\
\hline & Total & 756 & & \\
\hline
\end{tabular}

Test Statistics ${ }^{\mathrm{a}}$

a. Grouping Variable: Law

\begin{tabular}{lr}
\hline & \multicolumn{1}{c}{ Return } \\
Mann-Whitney U & $\mathbf{9 9 3 7 , 0 0 0}$ \\
Wilcoxon W & $\mathbf{1 0 8 2 8 3 , 0 0 0}$ \\
Z & $\mathbf{- , 0 3 4}$ \\
Asymp. Sig.(2-tailed) &, 973 \\
\hline
\end{tabular}

Table 7. Mann-Whitney Test Medium-High Ranks

\begin{tabular}{rlrrr}
\hline & & \multicolumn{1}{c}{ Mean } & \multicolumn{1}{c}{ Sum of } \\
& Law & N & Rank & \multicolumn{1}{c}{ Ranks } \\
return & medium & 567 & 427,64 & 147962,50 \\
& High & 693 & 369,51 & 163692,50 \\
& Total & 1260 & & \\
\hline
\end{tabular}

Test Statistics ${ }^{a}$

a. Grouping Variable: Law

\begin{tabular}{lr}
\hline & \multicolumn{1}{c}{ Return } \\
Mann-Whitney U & $\mathbf{6 5 3 4 6 , 5 0 0}$ \\
Wilcoxon W & 163692,500 \\
\hline Z & $\mathbf{- 3 , 5 5 5}$ \\
Asymp. Sig. (2-tailed) &, 000 \\
\hline
\end{tabular}


The Kruskal Wallis test statistic shows that there are differences in returns between countries with low, medium and high litigation risk with the rule of law as an indicator.

This result is consistent with Stulz and Williamson [8] where in their study shows that the development of the stock market is correlated with the legal origin of a country (common law vs. civil law). Meanwhile Salaber [2] shows that the sin stock return is higher in countries with higher litigation risk. Both use the rule of law as an indicator of both civil law and litigation risk. La Porta, Lopez-de-Silanes, Shleifer and Vishny [7] define the rule of law as an assessment of the tradition of law and order in a country.

In the data above, Indonesia is the only country with a low rule of law category, namely 33.03, while there are 7 countries that have a medium rule of law with an average of 53.95, these two categories produce significant differences in returns. Likewise, if Indonesia is compared with 6 countries in the high rule of law category with an average of 92.11 it results a significant difference.

Thus, if the rule of law is an assessment of the tradition of law and order in a country, then each country, especially the low and medium categories, should continue to improve the quality of law and its enforcement. Improving the quality of the law can be done by focusing on 3 important aspects, namely the effectiveness of the corrective system (sanctions), nondiscrimination and anti-corruption policies so that the development of the stock market increases and can compete with developed countries.

\section{Conclusion}

The capital market is a measure of a country's economic success through its stock transactions. Stocks that are quite interesting are those that produce high returns. But business law always says that high risk high return. Likewise, sin stock is considered quite sexy because it generates high returns. However, the existence of sin stock is considered unethical and tends to violate social norms, especially legal norms. Therefore, sin companies/industries are always faced with the risk of litigation.

The risk of litigation varies from country to country. These differences are grouped into the low, medium and high litigation risk categories. The results of the analysis reveal that there are differences in sin stock returns in the three categories. Significant differences occurred in the low-medium and low-high categories, while the medium-high was not significant. This result is in line with a number of studies which show that risk litigation with the rule of law as an indicator is correlated with stock market developments, especially sin stocks.

\section{References}

[1] Hong, H., and M. Kacperczyk.: The Price Of Sin : The Effect of Social Norms on Markets. Journal of Financial Economic, 93, 15-36 (2009)

[2] Salaber, J.: The Determinants of Sin Stock Returns: Evidence on the European Market. Working Paper, Paris Dauphine University, November (2007)

[3] Fabozzi, F., K.C. Ma., Oliphant.: Sin Stocks : A Natural Hedge. Working Paper (2008)

[4] Wiley, J., \& Soon.: Introduction to Organic Chemistry. ttp.: t.p., hlm 487 (2011)

[5] Dermawan, Sjahrial.: Manajemen Keuangan Lanjutan Edisi Revisi. Jakarta: Mitra Wacana Media hal 119. (2014) 
[6] Jogiyanto.: Teori Portofolio dan Analisis Investasi Edisi Kesepuluh. Yogyakarta: BPFE hal 265 (2015)

[7] La Porta., Lopez-de-Silanes., Shleifer., \&Vishny.: Legal Determinants of External Finance. NBER Working Paper No. 5879. January (1997)

[8] Stulz, R M., \& Williamson, R.: Culture, Opennes, and Finance. Journal of Financial Economic 70, hal 383-349 (2003)

[9] https://finance.yahoo.com

[10] http://info.worldbank.org

[11] https://tobaccoatlas.org/wp-content/uploads/2018/03/TobaccoAtlas_6thEdition_LoRes_Rev0318. pdf 